\title{
ECONOMIA E POLÍTICA NO DEBATE SOBRE O FENÔMENO DO BONAPARTISMO
}

\author{
Carlos Prado*
}

\begin{abstract}
Resumo: O objetivo do presente artigo é discutir o surgimento do Estado bonapartista a partir da leitura d'O 18 Brumário de Karl Marx. Essa obra tem suscitado diferentes interpretações e grandes debates sobre conceitos fundamentais. Buscaremos enfatizar que o bonapartismo não é resultado de condições puramente econômicas, mas da história enquanto luta de classes. Dessa forma, evidenciaremos o papel dos aspectos subjetivos, as estratégias e as ações dos homens e das classes na luta política e na transformação histórica.
\end{abstract}

Palavras-chave: Bonapartismo; História; Luta de classes.

Abstract: The purpose of this article is to discuss the emergence of the Bonapartist state from the reading of The 18th Brumaire of Karl Marx. This book has given rise to different interpretations and great debates about fundamental concepts. We'll seek to emphasize that Bonapartism is not the result of purely economic conditions, but of history as class struggle. Thus, will highlight the role of subjective aspects, strategies and actions of men and classes in the political struggle and the historical transformation.

Keywords: Bonapartism. History; Classes Struggles.

* Graduadoem História pela Universidade Católica Dom Bosco (UCDB). Mestre em Filosofia pela Universidade Estadual do Oeste do Paraná (UNIOESTE). Atualmente é professor do Departamento de História da Universidade Federal de Mato Grosso do Sul (UFMS). E-mail: carlosprado1985@hotmail.com. 
$\mid 176$ |

Economia e Política no debate..

Em meados do século XIX, a França carregava peculiaridades históricas que a colocava numa posição privilegiada, pois desde o final do século XVIII, com o advento da revolução francesa, se situava num lugar de destaque no cenário Europeu. Por suas características históricas, Marx considera que a França era o país mais avançado do velho continente no desenvolvimento das contradições sociais e econômicas. Por conseguinte, o proletariado francês era conscientemente mais adiantado e desde Babeuf, passando pelos socialistas utópicos, a sociedade das mercadorias começava a ser posta em questão. ${ }^{1}$

A França era o país símbolo da revolução burguesa e parecia caminhar para um novo momento de transformações. A luta de classes se manifestava de forma decisiva, as contradições econômicas do capital encontravam suas representações em reivindicações políticas. Diante da revolução de fevereiro de 1848 , quando a burguesia com a ajuda do proletariado, derrubou a monarquia de julho e fundou a segunda república francesa, Marx não teve dúvidas de que se iniciava um novo período revolucionário na história europeia.

Passada a turbulência das lutas políticas, Marx se dedicou a análise dos fatos. Sobre os eventos de 1848, ele publicou uma série de artigos cobrindo especialmente os acontecimentos alemães e franceses. Suas obras mais importantes desse período são A burguesia e a contrarrevolução, As lutas de classes na França e O 18 Brumário de Louis Bonaparte, o primeiro aborda a revolução burguesa alemã e os outros dois tratam da ascensão bonapartista na França.

\footnotetext{
${ }^{1}$ No prefácio para a terceira edição Alemã de O Dezoito Brumário, Engels afirma: "A França é o país em que, mais do que em qualquer outro lugar, as lutas de classe foram sempre levadas ao seu termo decisivo e onde, por conseguinte, as formas políticas mutáveis nas quais se processam essas lutas e nas quais se condensam seus resultados adquirem contornos nítidos. (...) Esta é a razão pela qual Marx não só estudava a história anterior da França com especial predileção, como também seguia sua história contemporânea em todos os detalhes, reunindo materiais destinados a futura utilização. Por isso, neste terreno nunca se via surpreendido pelos acontecimentos. (apud MARX, 2000, p. 12).
} 
Em O 18 Brumário de Louis Bonaparte, Marx analisa atentamente o curso da história durante a segunda república francesa, desde a queda de Louis Philippe, até o golpe de Estado de Louis Bonaparte. Para McLellan (1990, p. 261) essa obra de Marx, é "o seu mais brilhante panfleto político". Sem dúvida, o principal diferencial desse texto é que nele se desenvolve uma análise de conjuntura. Trata-se de uma análise histórico- política, no qual o objetivo não é a formulação de leis gerais e análises abstratas, mas a compreensão de um evento em específico, de um período determinado.

O objetivo do presente artigo é discutir como a bibliografia pertinente ao tema tem buscado explicar o surgimento do Estado bonapartista a partir da leitura d'O 18 Brumário. Para tanto, faremos uma revisão bibliográfica, comentando as principais obras sobre essa temática, expondo as diferentes concepções e discutindo suas polêmicas. Buscaremos evidenciar como essa obra tem suscitado diferentes interpretações e grandes debates sobre pontos fundamentais da obra de Marx. Nossa leitura buscará enfatizar que para Marx, o bonapartismo não é resultado de condições puramente econômicas pré-determinadas, mas da história enquanto luta de classes. Dessa forma, buscaremos enfatizar os aspectos subjetivos evidenciando que a história não é determinada de antemão, mas é resultado das estratégias e das ações dos homens que atuam na luta política.

\footnotetext{
A teoria economicista de Sader

O Filósofo e Cientista Político Emir Sader foi um dos primeiros estudiosos brasileiros a se dedicar à análise d' $O 18$ Brumário. Sua obra intitulada O Estado e a Política em Marx, publicada na década de 1990 foi escrita no final da década de 1960, durante o curso de pós-graduação em Filosofia. No segundo capítulo desse texto, intitulado O bonapartismo: o Estado na política de Marx, Sader discorre longamente sobre a queda da segunda república francesa e a ascensão de Louis Bonaparte ao poder. Por muito tempo essa
} 
obra serviu de base para os brasileiros que gostariam de estudar o tema, tornando-se uma referência constante em artigos e teses que abordavam a política em Marx.

Ao analisar o texto de Sader (1998), o que mais chama a atenção é a visão economicista, determinista e evolucionista que transparece nas entrelinhas de sua abordagem. Ele explica alguns dos principais eventos históricos como resultado direto das condições econômicas. É assim que ele aborda a ascensão da monarquia de julho em 1830, a revolução de 1848 e o triunfo do bonapartismo em 1851. Demonstra que os três principais eventos políticos da França pós-napoleônica estão diretamente relacionados às necessidades econômicas de um país que vive um período de desenvolvimento capitalista. Em suas palavras: "Ficou delineado como os fatos históricos dependem, em seu peso, do momento de instauração e desenvolvimento do modo de produção capitalista" (1998, p. 113).

O autor busca explicar o desenvolvimento histórico como resultado apenas das necessidades econômicas. Sua análise dá pouca ênfase ao papel que a política desempenhou, ou seja, ao papel da luta de classes diante dos conflitos sociais que abalavam a França. O papel que a classe operária desempenhou em fevereiro e junho de 1848 é menosprezado pelo autor ao enfatizar que esta ainda não estava consciente de seus interesses. Sader aponta que: "A classe operária estava ainda insuficientemente organizada, e os outros setores sociais se definem pela heteronomia em relação a essas classes, de tal forma que o campo ficou livre para o acesso da burguesia industrial ao Estado." (1998, p. 65).

Nesse texto, Sader (1998) pouco discute sobre a aliança entre a burguesia e a classe operária no processo de luta contra a monarquia de julho e também não se preocupa em analisar o levante operário de junho e as razões da derrota dessas jornadas. Sua análise parece presa à leitura determinista e economicista ao enfatizar que os eventos políticos são simplesmente uma forma de atualizar a superestrutura às necessidades da infraestrutura. Segundo essa leitura, o bonapartismo aparece como o resultado de uma evolução econômica, pois segundo sua análise: "A revolução 
de 1848 representa a cristalização do capitalismo no França, pela hegemonia do capital industrial." (1998, p. 96). Sader acredita que a queda da monarquia de julho, colocou fim ao domínio exclusivo da burguesia aristocrática e abriu caminho para a ascensão da burguesia industrial, demarcando o triunfo ou a consolidação final do capitalismo em terras francesas. Por conseguinte, sua leitura afirma que o Estado bonapartista aparece como a forma política correspondente a essa nova realidade econômica. Ele observa que: "O Estado precisa corresponder às necessidades de reprodução, das relações de reprodução no capitalismo" (1998, p. 73).

Sader (1998) interpreta O 18 Brumário a partir de uma leitura evolucionista da história. Dessa forma, à medida que progride as relações de produção e as forças produtivas, o Estado se adequa e apresenta formas superiores de organização. Por conseguinte, a revolução de 1848 significou o triunfo da burguesia industrial na França, rompendo com o monopólio da burguesia aristocrática, abrindo caminho para o capital industrial se desenvolver de forma plena, consolidando a hegemonia do capitalismo em território francês. Nessa perspectiva, o autor aponta que: “O Estado bonapartista corresponde à fase de hegemonia em que, ao reproduzir de forma multiplicada suas relações de produção, o capital superou o Estado liberal" (1998, p. 97).

Em sua leitura mecanicista, Sader (1998) distingue etapas do desenvolvimento capitalista e observa que para cada uma dessas fases do desenvolvimento econômico existe uma forma estatal correspondente. Segundo sua análise: “Há uma forma tradicional de apropriação do Estado pela burguesia, que é República Parlamentar; ela corresponde à fase de luta da burguesia pela instauração das relações capitalistas de produção". (1998, p. 9798). Porém, ele observa que uma vez superada essa etapa, o Estado precisa se desenvolver para uma forma superior, que segundo sua leitura, é historicamente mais avançada, e correspondente à hegemonia capitalista. Sader escreve que: "Marx aponta o Bonapartismo como uma forma historicamente superior de apropriação do Estado pelas classes dominantes" (1998, p.99). 
| 180 |

Economia e Política no debate..

Por fim, ele acrescenta que o golpe de Bonaparte "não é um episódio contingente na história política francesa. (...) O 18 brumário é o fim do desenvolvimento da centralização do poder estatal que teve início ao tempo da monarquia absoluta e do declínio do sistema feudal" (1998, p. 80). O golpe de Estado de Napoleão III é explicado como resultado de um processo progressivo da história, como a continuidade de um movimento de centralização do Estado, em curso desde a ascensão da burguesia em luta contra o antigo regime.

Obonapartismo e a centralização do Estado são interpretados como a forma política correspondente ao capitalismo em seu pleno desenvolvimento. O golpe de Louis Bonaparte não significa um retrocesso ou resultado da contrarrevolução, nem está inserido num processo de repetição histórica, pelo contrário, Sader (1998) encara essa forma de Estado como resultado do progresso econômico, como um avanço, ou seja, como a forma mais avançada do Estado capitalista.

Ao enfatizar que o bonapartismo é a forma estatal correspondente ao desenvolvimento das forças produtivas capitalistas, Sader (1998) consolida sua interpretação baseada em uma leitura economicista e determinista. Essa interpretação pode ser questionada não apenas em termos conceituais, abstratos, como também pela própria história do século XIX e XX. Pois se para Sader, o bonapartismo "revela-se como a verdade do Estado burguês" (1998, p. 105), então, ele não é uma exceção histórica, mas uma forma estatal que deve se desenvolver em todos os Estado que alcançam o desenvolvimento do capitalismo industrial, e isso não corresponde à realidade histórica.

A leitura de Sader (1998) concebe o Estado como epifenômeno da economia, ou seja, como resultado necessário e pré-determinado do avanço das relações econômicas. Tal interpretação menospreza qualquer tentativa de sistematização da luta de classes e do poder político, pois todos os níveis sociais seriam condicionados pela infraestrutura econômica.

Em contrapartida, recusar as análises economicistas e deterministas, não significa buscar respostas num quadro teórico 
que menospreze totalmente a relação entre economia e política. Não se trata de negar o economicismo e advogar a favor de uma análise que menospreze totalmente os efeitos que a infraestrutura provoca na organização política. Não se trata de promover uma separação absoluta dos níveis político e econômico. É um equívoco conceber a política como o terreno da liberdade absoluta, pois a mesma também sofre limitações que constrangem e condicionam a ação dos homens. Essas limitações impostas à luta política são colocadas pela própria esfera econômica, não como um determinismo, mas como um cerceamento das possibilidades.

É certo que os homens atuam sobre uma estrutura social dada, mas isso não transforma a história em um caminho pré-determinado. A estrutura econômica fornece as condições em que se desenvolvem os conflitos, mas não o seu resultado concreto. A história enquanto luta de classes não é projetada teologicamente por determinações estruturais. As condições econômicas não criam uma necessidade instransponível, mas uma necessidade relativa, pois a luta de classes é aberta a ação humana. É nesse momento que o político entra em cena, ou seja, o homem como agente histórico capaz de transformar o curso dos acontecimentos. As estratégias políticas, as ações e as incertezas constituem uma realidade dinâmica e aberta.

Sobre essa questão em debate, Codato (2004) apresenta uma proposta muito interessante:

O "econômico" tem, portanto, de ser tomado, nesse contexto, como o princípio base de organização da vida social que não deve ser contornado nem pode ser negado. Assim, "o econômico" não se confunde com "a economia" (no sentido de atividade econômica vulgar, como prática econômica ou como acontecimentos econômicos) e a "primazia do econômico" refere-se ao papel dominante das estruturas econômicas, e não a uma relação de causação simples entre razões econômicas estritas ("motivações") e condutas políticas empiricamente verificáveis ("ações"). (2004, p. 102). 
|182 |

Economia e Política no debate...

O econômico é o princípio de organização social construído historicamente. É sobre essa base econômica que a sociedade se organiza e estabelece relações de trabalho. Por conseguinte, essa organização social aparece como o alicerce determinando as condições materiais dos agentes históricos e a luta entre as classes. Esse econômico impõe limitações ao político, à medida que determina os interesses gerais postos em confronto. Portanto, ao fornecer o princípio geral de organização da sociedade, o econômico apresenta as condições históricas em que a luta de classes é travada, mas não condiciona o seu resultado. Não se trata de um determinismo econômico, mas apenas da imposição de condições e limites para a atuação política. Esse é o ponto a ser questionado na interpretação de Sader (1998), pois sua leitura não busca compreender o fenômeno do bonapartismo a partir da análise da luta de classes, observando os fatores subjetivos, mas apenas no desenvolvimento econômico objetivo, compreendendo o golpe de Louis Bonaparte como resultado natural e inevitável do crescimento das forças produtivas.

\section{Barsotti e a contrarrevolução burguesa}

Outro texto muito interessante para a análise dessa problemática em Marx é a tese de Barsotti (2002), intitulada; Marx, defensor do estado? O estado, a política e o bonapartismo no pensamento marxiano. $\mathrm{O}$ autor também compreende a ascensão do Estado Bonapartista a partir da passagem em que Marx afirma que as revoluções burguesas tem desenvolvido o Estado, aprimorando a sua centralização. O raciocínio desenvolvido por Barsotti expressa similaridades com a interpretação apresentada por Sader (1998):

(...) todas as revoluções que a burguesia opera, na realidade serão consideradas como revoluções políticas, isto é, de aprimoramento e aperfeiçoamento de seu Estado e de sua dominação. Cada passo desse processo determinava uma forma específica de Estado 
correspondente aos interesses materiais das frações

burguesas. (2002, p. 281).

Essa passagem deixa evidente que para o autor, o bonapartismo aparece como resultado do desenvolvimento da forma centralizada de Estado que seria determinado pelas condições materiais do capitalismo. Barsotti (2002) se apoia na tese economicista de que cada fase do desenvolvimento econômico capitalista apresenta uma forma específica de Estado, que sempre corresponde às necessidades da base econômica. Essa interpretação aponta para uma história progressista e evolucionista que se manifesta na evolução constante da forma estatal mediante revoluções políticas lideradas pela burguesia em favor dos seus interesses econômicos. Barsotti acrescenta que:

\begin{abstract}
À luz dessa experiência histórica é que Marx extrai as leis de tendência do desenvolvimento do Estado moderno, isto é, de seu aperfeiçoamento burocrático e de seu caráter repressivo e opressivo, o que coloca o bonapartismo como uma forma superior e não, como querem alguns, um acidente histórico ou um momento de descuido e destempero do estado capitalista. (2002, p. 316).
\end{abstract}

Essa passagem é ainda mais clara ao enfatizar o caráter necessário e evolucionista do Estado bonapartista. Assim como Sader, ele aponta o bonapartismo como forma superior, como um último estágio do desenvolvimento do Estado capitalista, como a manifestação de uma tendência histórica. Barsotti desenvolve essa mesma leitura no artigo intitulado, O bonapartismo em Marx, no qual busca comparar o primeiro e o segundo Bonaparte, enfatizando o desenvolvimento progressivo da forma estatal que se tornou cada vez mais centralizada, burocrática e repressiva. Eis mais uma importante passagem: “(...) a farsa não parece ser um acidente histórico, mas sim o ponto máximo da linha de aperfeiçoamento e ampliação da máquina estatal, centralização do 
poder no executivo, de autonomia do estado burguês desenhada desde a sua gênese" (Barsotti, 2011, p. 12).

Essas citações são suficientes para percebermos as similaridades entre ambas as interpretações apresentadas. Nas quais o bonapartismo aparece como uma forma superior de Estado, correspondente aos interesses materiais da burguesia. Essa interpretação compreende a formação de um Estado centralizador como um desenvolvimento necessário, como resultado de uma tendência histórica. Não se trata de uma contingência, mas do resultado final de uma evolução progressista da forma burguesa de Estado que é determinada pelo desenvolvimento das forças produtivas.

Não obstante, as similaridades entre os textos de Sader (1998) e Barsotti (2002) param por aí. Pois para o segundo, a centralização que caracteriza o bonapartismo não é resultado da hegemonia do capital na França, pelo contrário, é resultado do esgotamento da via revolucionária burguesa. Se por um lado, Sader encontra o nexo causal do bonapartismo no avanço hegemônico do capital na França, por outro lado, Barsotti parece identificar uma crise e um declínio do domínio burguês em território francês.

Barsotti (2002) desenvolve sua argumentação se apoiando na passagem em que Marx (2000, p. 47-48) afirma que se em 1789 "A revolução move-se, ao longo de uma linha ascencional. Com a revolução de 1848 acontece o contrário. (...) a revolução move-se em linha descendente". Marx aponta que se a revolução francesa cumpriu suas tarefas históricas, a revolução de 1848 iniciou um "movimento regressivo". Partindo dessa análise, o autor afirma que o processo revolucionário burguês se encerra em 1830, data na qual, se instala do domínio efetivo do capital na França, juntamente com a monarquia de julho. Nessa perspectiva, a revolução de 1848 e o golpe de Louis Bonaparte são símbolos não do apogeu do desenvolvimento capitalista, mas do início da sua decadência.

Barsotti (2011) ressalta que durante as jornadas de fevereiro e de junho, a burguesia assistiu a ascensão do movimento operário e a luta por uma república social e foi esse ascender da luta do proletariado que determinou o fim das pretensões revolucionárias 
da burguesia, demarcando o seu recuo. Para o autor o nexo causal do bonapartismo não é o desenvolvimento econômico capitalista, mas uma crise de dominação burguesa. Crise essa que aponta para o início de um período contrarrevolucionário. Barsotti afirma que “(...) a burguesia na luta contra a revolução, quanto mais degrada o seu poder parlamentar, mais fortalece o executivo e sua máquina estatal burocrática e repressiva" (2011, p. 13).

Durante as revoluções de 1848, ficou evidente que o proletariado aparecia no cenário político como uma nova classe social. Em fevereiro se estabeleceu uma aliança entre os operários e a burguesia, mas que foi quebrada logo em seguida diante do antagonismo dos interesses. As jornadas de junho evidenciaram justamente a separação entre essas duas classes, quebrando com o espírito fraternal existente e colocando em pauta uma nova luta. As jornadas de junho marcaram a ascensão do espectro do comunismo. A ameaça do perigo vermelho começava a rondar a Europa.

E dentro desse cenário que Barsotti (2002) aponta o bonapartismo no quadro da contrarrevolução. Ele escreve que a burguesia "Vai aperfeiçoando, ampliando e centralizando a máquina estatal até encontrar, no golpe de dezembro de 1851, a forma mais eficaz e capaz de garantir a ordem e tranquilidade necessárias". (2002, p. 282). A intranquilidade, que tirava o sono da burguesia era justamente a ameaça da revolução social. Dessa forma, o autor afirma que o golpe de Louis Bonaparte representa o triunfo da contrarrevolução burguesa, pois 1848 determina o fim do projeto revolucionário da burguesia que diante da ameaça proletária, só pôde manter o seu poder se apoiando em um governo autoritário, centralizado e despótico.

Nessa leitura, o bonapartismo não é apenas resultado do desenvolvimento econômico, mas é resultado também da luta de classes. A ditadura bonapartista, centralizada e autoritária aparece para a burguesia como o melhor modelo de Estado por que é capaz de apaziguar as massas pela força, impedir o debate político, livrando-a dos constantes conflitos políticos postos pela república parlamentar. Assim, a burguesia deixava de ser refém 
| 186 |

Economia e Política no debate..

das eleições e do debate infrutífero do parlamento. Para manter o seu domínio, a burguesia rompeu com a república e se apoiou no autoritarismo, capaz de proporcionar pela força e repressão a tranquilidade necessária para os seus negócios.

Leitura muito similar a de Sader e Barsotti encontramos na tese de Assunção (2005), intitulada Pandemônio de infâmias: classes sociais, Estado e política nos estudos de Marx sobre o bonapartismo. A autora também apoia sua argumentação na ideia de um desenvolvimento progressista da forma estatal em direção à centralização e burocratização. Ao se questionar sobre a origem desse Estado centralizador, ela afirma que ele "Surgiu do - e apressou o - declínio do sistema feudal, ainda na era da monarquia absoluta" (2005, p. 188). Assunção aponta que essa forma estatal teve suas origens no período anterior as revolução burguesas, mas que a tarefa foi concluída passo a passo pelas transformações políticas que se sucederam à queda do antigo regime.

A autora acrescenta que "a Revolução Francesa de 1789 daria andamento à tarefa que a monarquia iniciara: a centralização (...) Napoleão aperfeiçoou este aparelho e as monarquias francesas do século XIX apenas dividiram melhor as tarefas." Assunção também compreende que a ascensão do bonapartismo não é resultado do acaso ou da contingência histórica, mas representa o desenvolvimento de um Estado burocrático e repressivo, processo que tem início antes mesmo da revolução francesa e que está ancorado na ascensão econômica da burguesia.

E de forma muito similar a Barsotti (2002), a tese de Assunção caracteriza o bonapartismo com o traço da contrarrevolução, expressão política da burguesia em sua luta contra a classe operária. Ela afirma que:

O bonapartismo é a forma clássica de supremacia da burguesia em seu período contrarrevolucionário; (...) símbolo da decadência e da mesquinharia em que vivia a burguesia agora contrarrevolucionária, a única forma de governo possível numa sociedade na qual a burguesia já estava em decadência, tinha perdido a iniciativa política, e o proletariado ainda não alcançara 
a maturidade suficiente para impor sua própria pauta.

(2005, p. 197).

O bonapartismo aparece para Assunção como resultado de uma crise política, num período em que a burguesia e o proletariado se mostram incapazes de assumir as rédeas do Estado de forma direta e dirigi-lo segundo os seus interesses. Essa interpretação se baseia em uma famosa passagem de A guerra civil na França, quando Marx (2011, p. 56) observa que o Estado bonapartista "era a única forma de governo possível em um momento em que a burguesia já havia perdido e a classe operária ainda não havia adquirido a capacidade para governar a nação".

\section{Antunes e a crise da direção proletária}

No artigo intitulado Marx diante da ditadura bonapartista, Antunes (2009) também compreende o golpe de Louis Bonaparte como resultado de um processo contrarrevolucionário encabeçado pela burguesia. Antunes (2009), assim como Barsotti (2002) e Assunção (2005), aponta que 1848 e a crise que se sucede a partir da instauração da república, revelam o esgotamento das forças revolucionárias da burguesia, abrindo o caminho da decadência e da contrarrevolução diante do perigo da ascensão proletária. Ele observa que: "O bonapartismo seria para Marx a consequência lógica e necessária do fim da modernidade capitalista, do esgotamento de suas energias revolucionárias e da necessidade de salvá-la a qualquer preço de suas contradições" (2009, p. 56).

É interessante notar que Antunes (2009) encontra a origem do bonapartismo na incapacidade demonstrada pela burguesia e pelo proletariado para governarem e organizarem o Estado. $\mathrm{O}$ autor afirma que o golpe de Bonaparte que colocou fim a segunda república francesa foi "resultado da incapacidade demonstrada tanto pela burguesia quanto pelo proletariado para controlar o poder do Estado. (...) Em meio ao vazio e a instabilidade de poder que se criaram durante o período de crise política" (2009, 
| 188 |

Economia e Política no debate..

p. 57). Antunes encontra as raízes do golpe de Louis Bonaparte na luta política, na incapacidade das classes se colocarem a frente do poder do Estado.

Tornar-se necessário então investigar a origem dessa crise política e as razões para o fracasso da burguesia e do proletariado e é justamente nesse ponto que encontramos a diferença entre a análise de Antunes (2009) e dos outros autores já citados. Segundo sua argumentação: "A burguesia republicana teria sido deposta do parlamento por Bonaparte por conta de seu próprio cretinismo parlamentar (...) sua incapacidade para tomar verdadeiramente a direção do país e organizá-lo como uma nação burguesa" (2009, p. 59). O autor não encontra as razões da crise burguesa nas condições econômicas, mas na própria incapacidade política, posta pela luta de classes, mais precisamente na luta que se desenvolve entre o poder legislativo e executivo no período que se sucede as jornadas de junho e a vitória eleitoral de Louis Bonaparte.

Antunes também caracteriza a crise do proletariado: " $\mathrm{O}$ bonapartismo se funda, em última instância, (...) na crise da direção do proletariado e na sua incapacidade para se constituir como classe verdadeiramente revolucionária". (2009, p. 63). Essas passagens determinam a ascensão bonapartista a partir de uma crise política conjuntural, o que enfatiza o papel da luta política, da organização das classes em luta na transformação histórica. Ao enfatizar a crise de direção, Antunes enfatiza uma crise posta por fatores subjetivos, postos pela própria organização da luta política pela ausência de um programa revolucionário.

Essa leitura se torna ainda mais interessante quando a confrontamos com as leituras apresentadas por Assunção (2009) e Barsotti (2002), pois ambos também buscam caracterizar essa crise política do proletariado. Afinal, por que o proletariado não tomou o poder político? Por que ele saiu derrotado das jornadas de junho de 1848 ?

Sobre a incapacidade política apresentada pelo proletariado Assunção (2005, p. 62) afirma que: "No que pertine ao desenvolvimento do proletariado industrial, afirmava Marx, é sempre condicionado pelo da burguesia industrial" e acrescenta 
que "Ainda que a indústria francesa fosse avançada em relação ao restante do continente, a burguesia industrial não era a dirigente do processo" (2005, p. 117). Essa leitura aponta que as razões da incapacidade política do proletariado estão vinculadas apenas ao baixo desenvolvimento da indústria francesa, assim, o desenvolvimento da consciência política aparece como que atrelado ao desenvolvimento das condições materiais e, dentro dessa lógica, uma indústria imatura desemboca num proletariado imaturo para desempenhar sua função revolucionária. Assunção (2005, p. 118) conclui de forma clara: “Trata-se, portanto, não de uma debilidade ingênita, mas da imaturidade histórica da classe operária, determinada pela própria situação da indústria que a engendrava".

Não é difícil perceber as diferenças entre as concepções de Antunes (2009) e Assunção (2005). Enquanto o primeiro autor aponta que a crise se deu por condições políticas, o segundo cai num determinismo econômico, afirmando que a revolução proletária só é possível a partir de um amplo desenvolvimento industrial. Essa mesma interpretação economicista da derrota do proletariado encontramos na leitura de Barsotti. Ele afirma que: "Com uma indústria parcial, (...) o capitalismo francês dependente do comércio mundial, não oferecia um palco que colocasse com toda plenitude o proletariado frente à burguesia industrial e fornecesse o "conteúdo nacional da revolução"'" (2002, p. 292). Essa citação deixa claro que o autor também compreende a imaturidade ou incapacidade política do proletariado como reflexo direto de um baixo desenvolvimento industrial. Essa leitura economicista acaba por anular o papel dos homens na história, anula o fator subjetivo, anula o próprio sentido da luta de classes e desemboca numa visão determinista.

\section{Webb e a crítica ao socialismo utópico}

Para avançarmos nessa discussão se torna necessário apresentarmos a interpretação de Webb (2002). No artigo intitulado 
| 190 |

Economia e Política no debate..

The eighteenth brumarie as the key to understanding Marx's critique to utopian socialism, ele evidencia que uma das razões da imaturidade política do proletariado estaria na persistência de ideias utopistas em suas fileiras. Weeb afirma que:

Para Marx, os sistemas utópicos não tinham mais lugar no cenário político de meados do século XIX. O sistema de construção utópica tinha perdido toda a importância, todo valor prático e toda a justificativa teórica. Por esta razão, esse último recurso do proletariado às experiências doutrinárias é tomado como um indicador chave de sua própria derrota terrível após a insurreição de junho de 1848. (2002, p. 248-249 - Tradução nossa). ${ }^{2}$

Segundo Webb, O 18 brumário é uma obra fundamental para compreendermos a crítica de Marx ao socialismo utópico, pois o processo revolucionário de 1848 colocará em cheque todas as concepções fantasiosas oriundas dos teóricos utopistas. Essa corrente fantasiosa se esgotará nesse período diante do amadurecimento da luta de classes, evidenciando todos os limites desse socialismo doutrinário.

Webb observa que: "Marx lamenta o fato de que o partido do proletariado revolucionário ainda estava envolvido por frases utópicas. E isso não foi uma questão menor, de táticas partidárias mesquinhas. Pelo contrário, foi uma questão de profunda importância teórica e política" (2002, p. 251 - Tradução nossa). ${ }^{3}$

\footnotetext{
2 "For Marx, utopian systems had no place in the political landscape of the mid-nineteenth century. Utopian system-building had lost all importance, all practical worth and all theoretical justification. For this reason the proletariat's ultimate recourse to 'doctrinaire experiments' is taken as a key indicator of its own terrible defeat following the June insurrection of 1848".

3 "Marx bemoans the fact that the party of the revolutionary proletariat is still engaging in utopian phrasemongery. Nor was this a minor issue of petty party tactics. Rather it was an issue of profound theoretical and political importance".
} 
A posição fraternal do proletariado durante a revolução de fevereiro e a derrota em junho se deve em grande parte ao posicionamento equivocado da luta operária diante da conjuntura que se desenvolvia. Segundo Webb: “(...) os proletários foram fugindo de uma resolução real de conflitos sociais, e foram optando por evocar um inimigo distante através de ineficazes voos fantasiosos" (2002, p. 249 - Tradução nossa). ${ }^{4}$

Para o autor a diferença entre Marx e os utopistas é que o filósofo alemão descobriu as condições materiais para a emancipação do proletariado e que essa revolução é baseada nas condições reais de vida, e é nesse contexto que o pensamento utópico se torna reacionário, pois não se baseia na compreensão do presente, mas na fantasia, em ideias abstratas e distantes das condições materiais. Segundo Webb: “(...) eles estavam enganando as massas (e, muitas vezes eles próprios), ao mesmo tempo em que estavam anunciando-se como profetas" (2002, p. 250 - Tradução nossa). ${ }^{5}$

O texto de Webb (2002) é importante para compreendermos as razões da derrota proletária em junho de 1848, pois evidencia como a presença do utopismo nas fileiras do partido operário corroborou para o seu fracasso. Assim, a ascensão do proletariado como classe dominante não dependia apenas de um amadurecimento econômico, das condições materiais ou do desenvolvimento da indústria francesa, mas sim, da superação de ideias que impunham limitações à luta do partido operário. Aqui, a persistência do socialismo utópico no interior da organização da luta operária desempenha um papel determinante.

\footnotetext{
4 “ (...) the proletarians were evading a real resolution to social conflicts, and were opting instead to conjure the enemy away through ineffectual flights of fancy".

5 " (...) they were deceiving the masses (and often themselves) at the same time as they were heralding themselves as prophets".
} 
| 192 |

Economia e Política no debate...

\section{A incapacidade política das classes e a autonomia relativa do Estado}

Em As lutas de classes na França, Marx observa logo na abertura do texto que "todos os parágrafos mais importantes dos anais da revolução de 1848 a 1849 levam a epígrafe: Derrota da Revolução!" (1986, p. 49). Essa passagem, assim como todo o texto deixa evidente o sentido contrarrevolucionário da política burguesa que se consagrou vitoriosa derrotando a revolução social. Marx ainda acrescentou um comentário oportuno sobre a tragédia proletária ao afirmar: "Mas o que sucumbia nessas derrotas não era a revolução, eram os tradicionais apêndices pré-revolucionários" (1986, p.49). Os acontecimentos de fevereiro a junho de 1848 serviram para evidenciar que o socialismo doutrinário e utópico só poderia conduzir o proletariado a fracassos. A partir dessas jornadas ficou claro que não haveria emancipação no interior da ordem capitalista burguesa e que se a classe operária almejava libertar-se, seria preciso trilhar um caminho marchando separada da classe burguesa e para além da ordem capitalista.

Em O 18 Brumário Marx também faz uma importante crítica a essa atuação equivocada da direção operária na condução da luta política. Ele observa que a classe operária: “Lança-se em parte para experiências doutrinárias, bancos de troca e associações operárias, isto é, para um movimento no qual renuncia a revolucionar o velho mundo (...). (2000, p. 26). O proletariado preso a concepções doutrinárias pensava ser possível emancipar-se junto à burguesia, sem revolucionar a sociedade, ou seja, pensava ser possível conquistar a emancipação dentro da ordem burguesa capitalista. Questionando as ações estratégicas da luta operária, Marx observa que: "o proletariado de Paris ainda não era capaz de sair dos limites da república burguesa, a não ser nas suas ilusões, na sua imaginação; como agia sempre e por toda parte a serviço da república burguesa" (1986, p.71). Assim, o que a Comissão de Luxemburgo buscava era uma organização para o trabalho, mas o trabalho já havia sido organizado, sua organização era o trabalho livre e assalariado. 
Depois do fracasso da Comissão de Luxemburgo e da derrota nas jornadas de junho a classe operária só aparecerá na luta política como um apêndice da social democracia. Marx comenta: "Ao deixar-se guiar pelos democratas diante de tal acontecimento e ao trocar o interesse revolucionário de sua classe por um bemestar momentâneo, os operários renunciaram à honra de se tornarem uma potência conquistadora" (2000, p.78-79). Nessa passagem fica mais uma vez demonstrada à crítica de Marx a direção revolucionária operária, que não possuía um programa autônomo e independente e, nessas circunstâncias, se arrastrou atrás da Montagne, abandonando a luta por transformações verdadeiras. Essa ausência de um programa próprio da classe operária manifestada numa profunda crise de organização política foi um dos fatores decisivos para a ascensão do bonapartismo.

A burguesia reunida no partido da ordem também cumpriu um importante papel para a ascensão do bonapartismo, ao conduzir a política de forma equivocada. Marx em diversas passagens de $O$ 18 Brumário demonstra que o partido burguês fez escolhas erradas, se acovardou e tomou uma série de medidas que acabaram por fortalecer cada vez mais o poder executivo de Louis Bonaparte. Uma leitura atenta da obra de Marx evidencia não apenas os elementos objetivos, mas também abre espaço para o elemento subjetivo, para um terreno propriamente político. Marx mostra momentos de bifurcação histórica, critica a todo o momento a atuação da burguesia parlamentar, deixando claro que o aumento do poder executivo era resultado também da própria crise política da burguesia que se demonstrava incompetente politicamente. Segundo Marx: “(...) o partido da ordem demonstrou que não sabia nem governar, nem servir; nem viver, nem morrer; nem apoiar a república, nem derrubá-la" (2000, p.112).

Desde a derrota da classe operária, a luta política se esboçou pela oposição entre o partido da ordem que compunha a Assembleia Nacional e Louis Bonaparte, eleito presidente em dezembro de 1848. O triunfo do poder executivo em 1851 foi resultado direto dos inúmeros erros e falhas estratégicas da burguesia parlamentar. 
Vejamos alguns desses exemplos decisivos em que a incapacidade política burguesa prepara o terreno para o golpe de Bonaparte.

Um dos mais importantes momentos destacados por Marx ocorre em janeiro de 1849 quando a própria burguesia questiona o poder legislativo e, por meio do partido da ordem, dissolve a Assembleia Nacional. A constituição já estava elaborada, mas ainda se discutiam Leis Orgânicas. Mas a burguesia cansada de discussões insossas concluiu que para a consolidação do novo governo essas leis poderiam esperar. Segundo observa Marx (2000, p.42): "a dissolução era necessária para a restauração do crédito, para a consolidação da ordem, para por fim aos indefinidos arranjos provisórios e estabelecer uma situação definitiva".

A queda da Assembleia foi orquestrada pela própria burguesia em busca de estabilidade. O partido da ordem apelou ao povo contra a Assembleia, apelou contra as indefinições e debates sem fim. Segundo Marx (2000, 43): “Levaram, assim, as massas desorganizadas do povo à luta contra a Assembleia Nacional, expressão constitucionalmente organizada do povo." Além de fragilizar o poder legislativo, os burgueses, acrescenta Marx (2000, p. 43): "Ensinaram Bonaparte a apelar para o povo contra as assembleias parlamentares." Foram os próprios republicanos representantes da legalidade burguesa que impulsionaram Bonaparte para a trilha da tirania. Marx conclui: "Foi assim que o próprio partido da ordem, quando não constituía ainda a Assembleia Nacional, quando apenas era ministério, estigmatizou o regime parlamentar" (2000, p. 45).

A história da segunda república francesa tem na incapacidade política burguesa uma de suas principais características. Temendo a ascensão de uma oposição à esquerda, essa burguesia não tolerará a presença de representantes do proletariado, nem de socialdemocratas no parlamento. Não compreendendo a lógica da república e do jogo democrático, essa burguesia se revelará herdeira do antigo regime e amante do poder centralizado e despótico. Em D`un Napoléon l'autre, Barot analisa essa desastrosa atuação política e afirma: "Expulsando progressivamente do parlamento suas frações populares, entregando alguns deputados da esquerda, 
magistrados, etc. a burguesia e ela mesma, progressivamente colocou em descrédito, enfraqueceu o poder parlamentar" (p. 5354 - Tradução nossa). ${ }^{6}$ A queda da segunda república é obra da própria burguesia. Trata-se de um processo de autodestruição. Nesse sentido, Barot conclui que: "A burguesia, em três anos, foi coveira de sua própria política" (p. 51 - Tradução nossa). ${ }^{7}$

Outro momento decisivo em que Marx destaca a incapacidade política burguesa, colocando seus erros estratégicos como determinantes para o curso dos acontecimentos se deu a partir das eleições parciais de 10 de março de 1850. O resultado das urnas apontou uma vitória massacrante dos candidatos socialdemocratas. Diante da derrota, Bonaparte ficou sem saída e surgia o momento certo para a burguesia orquestrar a sua queda. Marx comenta que depois das eleições, Bonaparte:

\begin{abstract}
(...) desapareceu atrás do partido da ordem. Rendeu-lhe tributo, pediu pusilanimemente perdão, prontificouse a nomear qualquer ministério que a maioria parlamentar ordenasse, chegou ao ponto de implorar aos dirigentes dos partidos orleanistas e legitimistas, aos Thiers, Berryers, Brogliés, Molés, numa palavra, aos chamados brugraves, que em pessoa assumissem a direção do Estado. (2000, p. 76).
\end{abstract}

Essa citação expressa claramente que o bonapartismo não era a única saída para a burguesia francesa, mas se tornou a melhor opção justamente pela incompetência dos seus parlamentares, pela sua covardia, pela ausência de um projeto ou um programa capaz de garantir a ordem e a tranquilidade no interior de uma república. Marx conclui afirmando que diante da maravilhosa oportunidade de tomar as rédeas do governo e dirigir o Estado de

\footnotetext{
6 "Expulsant progressivement du Parlament ses fractions populaires, livrant certains deputes trop à gauche aux magistrats, etc., la bourgeoisie a d`elle-même progressivement abaissé et décrédibilisé, affaibli le pouvoir parlementaire".

${ }^{7}$ La burgeoisie, em trois ans, fut son propre fossoyeur politique".
} 
| 196 |

Economia e Política no debate..

acordo seus interesses, "O partido da ordem não soube aproveitar este momento único. Em vez de tomar corajosamente o poder que lhe era oferecido, não obrigou sequer Bonaparte a reintegrar o ministério dissolvido" (2000, p. 76).

Ao enfatizar os aspectos objetivos e subjetivos da luta de classes, Marx compreende que o golpe não era um resultado necessário das condições econômicas. Ele destaca os fatores políticos, salienta os erros e equívocos das estratégias políticas adotadas pelo partido da ordem. Diante desse fracasso, Marx conclui que: "A burguesia industrial aplaude assim, com aplausos abjetos, o golpe de Estado de 2 de dezembro, a aniquilação do parlamento, a queda de sua própria dominação, a ditadura de Bonaparte" (2000, p. 126).

Para avançar um pouco mais nessa questão, tornar-se necessário fazer um breve comentário sobre a interpretação de Poulantzas (1971) sobre o bonapartismo, pois sua leitura nos possibilita compreender melhor a razão pela qual a burguesia abriu mão de sua república e aplaudiu o golpe bonapartista. Em seus estudos sobre o poder político na sociedade capitalista, Poulantzas traz uma interessante contribuição para a análise do conceito de bonapartismo. Em sua investigação sobre a natureza e tipos de Estados, o marxista grego aponta que o bonapartismo é uma forma concreta de Estado capitalista.

Segundo a interpretação de Poulantzas (1971), os estudos de Marx sobre a conjuntura política da segunda república francesa revelam o aspecto mais fundamental do Estado capitalista; a sua autonomia relativa diante das classes sociais. Esse seria para o autor a grande contribuição d'O 18 Brumário para a interpretação dos fenômenos políticos e do conceito de Estado na sociedade contemporânea.

Deve-se insistir que, para o autor, essa autonomia relativa do Estado diante das classes sociais não é uma característica singular do bonapartismo, mas de todos os Estados que se desenvolvem sob o modo de produção capitalista. Nesse sentido, qual é a especificidade do bonapartismo segundo Poulantzas? Para ele essa forma de Estado se diferencia dos demais tipos apenas no grau de 
autonomia. Por conseguinte, ele conclui que o Estado bonapartista se apresenta como o tipo sob o qual a autonomia relativa alcança uma maior intensidade.

Para Poulantzas (1971), essa autonomia relativa que o Estado capitalista alcança se evidencia na análise da superestrutura político-jurídica. Ao desenvolver a figura abstrata do 'cidadão', essa estrutura jurídica abstraem do homem suas condições históricas. Ele se transforma numa imagem abstrata e genérica, perdendo o seu vínculo de classe. Dessa maneira, os antagonismos entre as classes sociais e as contradições econômicas são encobertas por uma figura jurídica de caráter universal. Tal procedimento cria ideologicamente um efeito de isolamento dos sujeitos sociais que não se reconhecem como pertencentes a uma classe social determinada. Por conseguinte, o próprio Estado perde o seu caráter de classe e se apresenta como neutro e imparcial, como um Estado universal e abstrato representando a unidade política da nação.

Sendo a autonomia relativa uma característica geral dos Estados capitalistas, o bonapartismo apenas se diferencia de outras formas estatais por apresentar uma maior intensidade nessa autonomia, de maneira que o Estado pode acabar por substituir as representações de classes. Poulantzas afirma que:

O Estado pode também substituir esses partidos, continuando a funcionar como fator de organização hegemônica dessas classes. Pode também, em certos casos, tomar inteiramente a seu cargo o interesse político dessas classes: trata-se do fenômeno histórico do bonapartismo francês. Neste último caso, a autonomia relativa do Estado é tal que as frações dominantes parecerão renunciar ao seu poder político, tal como Marx descreve as suas análises relativas ao segundo Império. (1971, p.126).

Os estudos de Poulantzas (1971) nos ajudam a compreender as razões pelas quais a burguesia foi capaz de renunciar ao poder político; abrindo mão de construir a sua república para buscar refúgio e segurança num Estado autoritário e centralizado. Mesmo 
| 198 |

Economia e Política no debate..

sem a direção da burguesia, o Estado bonapartista continua reproduzindo a lógica capitalista. A autonomia relativa dá ao bonapartismo um caráter de Estado genérico. Na medida em que os representantes da burguesia não detêm em suas mãos o controle da máquina estatal, esse aparece desprovido do seu caráter de classe, numa espécie de "benfeitor patriarcal de todas as classes". Com um discurso que busca a "defesa da ordem", esse Estado parece se constituir como um poder independente. Em uma carta de 13 de abril de 1866, Engels escreve sobre a ascensão do bonapartismo na Alemanha:

(...) o bonapartismo é a verdadeira religião da burguesia contemporânea. Cada vez mais fica claro para mim que a burguesia é incapaz de governar diretamente, e por isso ali onde não existe oligarquia que em troca de uma boa remuneração (como se faz aqui na Inglaterra) pode-se encarregar de dirigir o estado e a sociedade no interesse da burguesia, a forma normal é a semiditadura bonapartista. Esta defende os interesses materiais essenciais da burguesia até contra sua própria vontade, mas ao mesmo tempo, não lhe concede acesso ao poder (político). (Engels, 1976 - grifos nossos).

Essa passagem sintetiza de forma clara o conceito de bonapartismo, pois aponta o caráter burguês dessa forma estatal e revela sua relativa autonomia. A revolução de 1848 evidenciou a ascensão do movimento operário e introduziu a burguesia em seu período contrarrevolucionário. Foi nesse momento que a classe dominante se mostrou incapaz de consolidar a sua república democrática e gerir diretamente os negócios do Estado. A classe burguesa se mostrava incapaz de governar. Foi nesse momento que ela abriu mão do seu poder político para não perder o seu poder social. 


\section{Referências}

ANTUNES, J. Marx diante da ditadura Bonapartista. In: Maisvalia, no ${ }^{2}$. São Paulo: Týkhe, 2009, p. 54-63.

ASSUNÇÃO, V. N. F. de. Pandemônio de infâmias: classes sociais, Estado e política nos estudos de Marx sobre o bonapartismo. 2005. Tese (Doutorado). PUC, São Paulo.

BAROT, E. D'un Napoléon l'autre: l'intelligibilité d’un étrange présent. In: MARX, Karl. Le 18 Brumaire de Louis Bonaparte. Paris: Le Livre de Pouche, 2007, p. 29-104.

BARSOTTI, P. D. Marx, defensor do estado? O estado, a política e o bonapartismo no pensamento marxiano. 2002. Tese (Doutorado). USP, São Paulo.

. O bonapartismo em Marx. In: Marx e o marxismo 2011: teoria e prática. Niterói, UFF. 2011.

CODATO, A. N. 18 Brumário, Política e pós-modernismo. In: Lua Nova, no 63.2004 , p. 85 - 116.

ENGELS, F. Carta de Engels a Marx de 13 de abril de 1866. In: LENIN, Vladimir Ilich. Acotaciones a la correspondência entre Marx e Engels - 1844/1843. Montevideo/Barcelona: Pueblos Unidos, 1976.

MCLELLAN, D. Karl Marx: vida e pensamento. Trad. Jaime Clasen. Petrópolis: Vozes, 1990.

MARX, K. A guerra civil na França. Trad. Rubens Enderle. São Paulo: Boitempo, 2011. . As lutas de classes na França. São Paulo: Global, 1986.

O dezoito brumário de Louis Bonaparte. Trad. Silvio Chagas. São Paulo: Centauro, 2000.

POULANTZAS, N. Poder político e classes sociais. Porto: Portucalense, 1971, $2 \mathrm{v}$. 
|200 |

Economia e Política no debate..

SADER, E. Estado e política em Marx. 2 ed. São Paulo: Cortez, 1998.

WEBB, D. Here content transcend phrase: the eighteenth brumarie as the key to understanding Marx's critique to utopian socialism. In: COWLING, M.; MARTIN, J. (eds.) Marx's Eigtheenth Brumaire: (Post) modern Interpretations, London: Pluto Press, 2002, p. $243-257$. 